\title{
Association of CXCR4 mRNA Expression with Clinicopathological Aspects of Invasive Breast Carcinoma
}

\author{
Novan Adi Setyawan ${ }^{1 *}$, Didik Setyo Heriyanto ${ }^{2}$, Naomi Yoshuantari ${ }^{2}$ Irianiwati $^{2}$ \\ 1. Department of Anatomic Pathology, Faculty of Medicine, Universitas Sebelas Maret \\ Surakarta, Indonesia \\ 2. Department of Anatomic Pathology, Faculty of Medicine, Universitas Gadjah Mada, \\ Yogyakarta, Indonesia \\ Correspondence: novan_uns@yahoo.com
}

\begin{abstract}
ABSTRAK
Pendahuluan: Karsinoma payudara merupakan keganasan paling sering pada perempuan. Jenis yang tersering adalah karsinoma (duktal) invasif tipe tidak khas. Prognosis pada karsinoma payudara dipengaruhi oleh banyak faktor, diantaranya usia, ukuran, derajat histologis dan metastasis limfonodi. Salah satu faktor prognosis yang berperan dalam perkembangan dan metastasis dari karsinoma payudara adalah kemokin reseptor CXCR4 dengan ligannya CXCL12. Penelitian tentang ekspresi CXCR4 pada karsinoma (duktal) invasif payudara dihubungkan dengan aspek klinikopatologi masih belum jelas. Penelitian ini bertujuan mengetahui perbedaan tingkat ekspresi mRNA CXCR4 antara berbagai aspek klinikopatologi pada karsinoma payudara invasif.

Metode: Sampel adalah blok parafin dari jaringan karsinoma payudara (duktal) invasif tipe tidak khas sejumlah 50, dibagi menjadi kelompok-kelompok yaitu dengan dan tanpa metastasis limfonodi, usia < 45 tahun dan > 45 tahun, ukuran kecil dan besar, derajat histologi baik dan buruk . Ekspresi mRNA CXCR4 diperiksa secara kuantitatif dengan metode qRT-PCR. Perbedaan ekspresi mRNA CXCR4 antara berbagai aspek klinikopatologi dianalisis dengan T-test atau Kruskal-Wallis.

Hasil: Dari 50 sampel yang diteliti didapatkan 26 sampel (52\%) dengan peningkatan ekspresi mRNA CXCR4 dibandingkan jaringan normal. Tidak didapatkan perbedaan bermakna ekspresi mRNA CXCR4 antara berbagai aspek klinikopatologi (>0.05) seperti status metastasis pada limfonodi, derajat histologi, ukuran tumor dan usia penderita. Namun demikian ekspresi mRNA CXCR4 meningkat pada karsinoma payudara apabila dibandingkan dengan jaringan payudara normal. Meskipun demikian, tingkat ekspresi CXCR4 secara tunggal tidak berhubungan dengan aspek klinikopatologi pada karsinoma payudara invasif.
\end{abstract}

Kesimpulan: Ekspresi mRNA CXCR4 tidak berbeda bermakna antara berbagai aspek klinikopatologi pada karsinoma payudara invasif.

Kata Kunci: karsinoma payudara invasive; ekspresi mRNA CXCR4; aspek klinikopatologi.

\begin{abstract}
Introduction: Breast cancer is the most common malignancy in women of which majority histological type is Invasive (Ductal) Carcinoma of No Special Type (NST). The prognosis in breast carcinoma is influenced by many factors such as age, tumor size, degree of histology, and lymph node metastasis. Another factor in the development and metastasis of breast cancer is the chemokine receptor CXCR4 and its ligand, CXCL12. Studies state that the expression of CXCR4 in Breast Invasive Carcinoma associated with clinicopathologic aspects remain unclear. This study aims to determine differences in the level of CXCR4 $m R N A$ expression between clinicopathologic aspects in breast carcinoma.
\end{abstract}




\begin{abstract}
Methods: A total of 50 samples of formalin-fixed paraffin-embedded (FFPE) tissues diagnosed as invasive breast carcinoma (NST) are used in this study. Samples are divided into groups, namely with and without lymph node metastasis, age $<45$ years and $>45$ years, small and large size, low grade and high grade. CXCR4 mRNA expression is quantitatively examined by qRT-PCR. CXCR4 mRNA expression differences between various clinicopathologic aspects were analyzed by T-test or Kruskal-Wallis.

Results: Of the 50 samples, 26 samples (52\%) revealed increased expression of CXCR4 mRNA compared to normal tissue. There were no significant differences in $m R N A$ expression of CXCR4 between various prognostic factors $(p>0.05)$ such as the status of lymph node metastasis, histologic grading, size, and age. However, the expression of CXCR4 mRNA is increased in breast carcinoma when compared to normal breast tissue. Nonetheless the level of CXCR4 expression alone is not associated to clinicopathologic aspects in invasive breast carcinoma.

Conclusion: CXCR4 mRNA expression did not differ significantly between the various clinicopathological aspects of invasive breast carcinoma.
\end{abstract}

Keyword: invasive breast carcinoma; mRNA of CXCR4; clinicopathologic aspects.

\section{INTRODUCTION}

Breast carcinoma is the most common malignancy in women. The incidence is about $23 \%$ of all malignancies in women in developed countries and increasing in developing countries ${ }^{1,2}$. Currently more than half the incidence of breast cancer occurs in developing countries ${ }^{2,3}$. The most common histologic type of breast cancer is invasive (ductal) carcinoma of no special type (NST) ${ }^{1}$.

The prognosis in breast carcinoma is strongly influenced by age, menopausal status, tumor size, lymph node metastasis, histological grade and tumor stage at diagnosis ${ }^{1}$. Breast carcinoma has a favorable prognosis when diagnosed early, whereas in metastatic cases the mortality rate is very high. The five-year survival rate in patients with localized breast carcinoma is around $90 \%$ and decreased dramatically to $20 \%$ if it has metastasized ${ }^{4}$.

Metastasis is the multistep and multi factorial process that includes many factors ${ }^{5,6}$. The process begins with local invasion in primary organ followed by intravasation of tumor cells into blood or lymph vessels, following blood or lymph flow, then by extravasation, the tumor cells undergo proliferation and colonization in new site. One of the factors that play a role in the tumor growth and metastasis is chemokine CXCR4 $4^{4,7}$.

CXCR4 is a $\mathrm{G}$ protein-coupled receptors that bind chemokines CXCL12, a chemoattractant, that functions in the activation, differentiation and cell circulation. The interaction of CXCR 4 and CXCL12 plays a role in the process of angiogenesis, proliferation, apoptosis and metastasis of tumor cells ${ }^{4,7}$. CXCR4 gene expression can be examined semi quantitatively using immunohistochemical techniques (IHC) or quantitatively using qRT PCR technique (Quantitative Real Time PCR) ${ }^{8,9}$. From existing, CXCR4 is associated with poor prognosis in breast carcinoma ${ }^{9-11}$. However, studies of CXCR4 in association with clinicopathological aspects, especially metastatic status in invasive breast carcinoma remain unclear. This Study is aimed to investigate the association between CXCR4 mRNA expression and metastatic status in invasive breast carcinoma. The study of CXCR4 expression in invasive breast carcinoma can further guide in determining prognosis and "molecularly targeted therapy" especially in the metastatic ones. This study 
aims to see variations within the level of CXCR4 mRNA expression between clinicopathologic aspects in breast malignant neoplastic disease.

\section{MATERIAL AND METHOD}

\section{Study Design and Subject}

A cross-sectional study was performed between September 2015 until December 2016. A total of 50 formalin-fixed paraffinembedded (FFPE) tissue samples of breast cancer which met the inclusion criteria obtained from the government hospital and private laboratories in Yogyakarta. The inclusion criteria include women, radical mastectomy procedure with lymph nodes, invasive breast carcinoma of no special type, no residual or recurrent case. The samples used consisted of 25 samples with lymph node metastasis and 25 samples without lymph node metastasis. Normal breast tissue is used as normal control. The data of lymph node status, tumor size, histologic grade, and age of the patient were secondarily collected from medical record. CXCR4 mRNA expression was obtained from qRT PCR examination.

\section{RNA Extraction}

RNA extraction and qRT-PCR process was performed in Anatomic Pathology laboratory, Faculty of Medicine, Universitas Gadjah Mada. Total RNA Mini Kit (Tissue) Protocol was used for RNA extraction. The protocol included sample preparation, cell lysis, RNA binding, washing, and RNA Elution. Samples prepared by cutting paraffin blocks with microtome in $7 \mu$ of thickness of as much as 5-8 pieces. Deparaffinization is then performed by adding a solution of xylol followed by absolute ethanol. Cell lysis is performed by adding $400 \mu 1$ of RB Buffer and $4 \mu \mathrm{l}$ of $\beta$-mercaptoethanol into tissue pellet. $400 \mu \mathrm{l}$ of $70 \%$ ethanol prepared in ddH2O (RNase and DNase-free) is used for RNA Binding. Washing step is performed by adding Wash Buffer (make sure ethanol was added). This process is repeated three times. Next is the addition of $50 \mu \mathrm{l}$ of RNase-free water followed by centrifugation at 14.000 rpm for 1 minute to elute the purified RNA. Purified RNA are kept at $-70{ }^{\circ} \mathrm{C}$.

\section{PCR Analysis}

RNA amplification and PCR analysis was performed using One-Step qRT-PCR protocol. The composition of each component used are as follows: $6.4 \mu \mathrm{l}$ of PCR-grade water, $10 \mu 1$ KAPA SYBR FAST qPCR Master Mix, $0.4 \mu 1$ deoxyuridine triphosphate, $0.4 \mu 1$ Forward Primer (GAPDHF atau CXCR4 F), $0.4 \mu$ l Reverse Primer (GAPDHR atau CXCR4 R), 0.4 $\mu$ l KAPA RT Mix and $2 \mu 1$ Template RNA. Primers used to make standard GAPDH and CXCR4 are presented in Table 1.

Table 1. GAPDH and CXCR4 primer sequences

\begin{tabular}{llll}
\hline & \multicolumn{2}{l}{ Forward Primer } & \multicolumn{2}{l}{ Reverse Primer } \\
\hline GAPDH & 5'-GCA TCC & 5'-TCC & ACC \\
& TGG GCT ACA & ACC CTG TTG \\
& CTG AG-3' & CTG TA-3' \\
CXCR 4 & 5'-AGC ATG & 5'-GAT & GAT \\
& ACG GAC AAG & ATG & GAC \\
& TAC C-3' & ACC & CTT \\
& & ACA.C3 & \\
\hline
\end{tabular}

Program of Real Time PCR following cycling protocol are presented in Table 2 using a DT lite Real-Time PCR System (DNA-Technology).

Table 2. Cycling Protocol of RT-PCR

\begin{tabular}{llll}
\hline Step & Temp & $\begin{array}{l}\text { Duratio } \\
\mathrm{n}\end{array}$ & $\begin{array}{l}\text { cycl } \\
\text { es }\end{array}$ \\
\hline Reverse & $42^{\circ} \mathrm{C}$ & $5 \mathrm{~min}$ & - \\
Transcription & & & \\
Enzyme inactivation & $95^{\circ} \mathrm{C}$ & $3 \mathrm{~min}$ & - \\
Denaturation & $95^{\circ} \mathrm{C}$ & $3 \mathrm{sec}$ & 40 \\
Annealing/extension & $60^{\circ} \mathrm{C}$ & $\geq 20 \mathrm{sec}$ & 40 \\
/dara acquisition & & & \\
\hline
\end{tabular}


RT PCR results in the form of a graph and number which is then converted into expression value using a formula as shown below:

CXCR expression $\quad: 2^{(-\delta \delta C T)}$

$\delta C T$ : PCR score of CXCR4 -PCR Score GAPDH

$\delta \delta \mathrm{CT}: \delta \mathrm{CT}$ sample $-\delta \mathrm{CT}$ normal tissue

\section{Statistical Analysis}

The data obtained were statistically processed to find differences of CXCR4 mRNA expression level between variables. The normally distributed data were analyzed using T-test and non-normally distributed data were analyzed using Mann-Whitney U Test or Kruskal-Wallis Test. All data analysis were performed in SPSS version 21 (IBM). A pvalue $<0.05$ was considered statistically significant.

The ethical problem that may arise in this study is the confidentiality of the patient's identity. In this study, the data to be submitted was in the form of a code without mentioning the name and laboratory number of the research subject. The identity will be converted into a code according to each group.

The ethical clearance letter issued by Medical and Health Research Ethics Committe (MHREC) Faculty of Medicine Gadjah Mada University with Ref number: KE / FK / 210 / EC / 2015.

\section{RESULT}

Fifty samples of breast cancer FFPE tissues are used in this study. The samples were divided into two groups, as many as 25 samples with axillary lymph node metastases and 25 samples without metastatic lymph nodes. Of the 25 samples with metastatic lymphnodes, 13 samples were from private laboratory while the rest were from the government hospital. Of the 25 tissue samples without metastasis, 12 samples were from private lab and the rest were from the government hospital. Normal breast tissue from government hospital was used as normal control.

Of the 50 samples obtained, there were 26 samples (52\%) which revealed increased expression of CXCR4 mRNA compared to normal tissue. The samples which produce higher level of expression both for group with (10 of 12 samples) and without lymph node metastasis (11 of 13 samples) were derived from government hospital tissues. These results are in contrast with samples coming from private laboratories where only 2 of 13 samples had high expression in the group with lymph node metastasis and 4 of 12 samples in the group without lymph node metastasis. This study also obtained three samples with very high CXCR4 expression (more than 1000) in non-metastatic group compared to the normal control (36.4). (data not shown)

There were no significant differences betweenCXCR4 mRNA expression level with respect to lymph node status, tumor size, histologic grade, as well as age of patient observed in this study (table3).

Table 3. Clinical Featuresand CXCR4 mRNA Expression

\begin{tabular}{ccc}
\hline Variable & CXCR4 & $\mathrm{p}(\mathrm{sig})$ \\
\hline \multicolumn{2}{c}{ lymph node status } \\
negative & $36,75(5,27-$ & \\
(n=25) & $3326,98)$ & \\
positive & $29,85(2,14-$ & \\
& $388,02)$ & $0.907(\mathrm{NS})$ \\
Tumor size & & \\
T1 $(\mathrm{n}=2)$ & $71,83(6,49-$ & \\
& $137,18)$ & \\
T2 $(\mathrm{n}=19)$ & $1351,17)$ & \\
T3 $(\mathrm{n}=29)$ & $29,85(4,28-$ & \\
Grade & $3326,98)$ & \\
$1(\mathrm{n}=0)$ & & \\
$2(\mathrm{n}=9)$ & $1,65(0,99)$ & $0.99(\mathrm{NS})$ \\
$3(\mathrm{n}=41)$ & $1,65(0.65)$ &
\end{tabular}




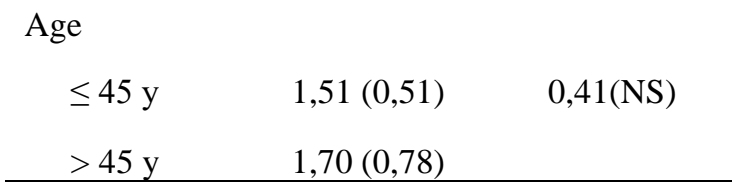

\section{DISCUSSION}

Various biological markers have been used as marker for prognosis and treatment of breast cancer. Currently the most commonly used marker in breast cancer is hormonal receptors such as ER, PR, and Her2 ${ }^{1}$. Other markers that are currently being researched and developed is chemokine receptor. Chemokines are chemotactic molecules which play role in inflammatory process, immune system, and also plays a role in tumor progression. Several studies have proven the role of chemokines in determining the tendency and sites of tumor metastasis ${ }^{4}$.

This study discusses mRNA expression of CXCR4 associated with clinicopathological aspects especially metastatic status. qRT-PCR method is used to assess the level of CXCR4 mRNA expression quantitatively. qRT-PCR examination using formalin-fixed paraffinembedded (FFPE) is routinely used and the results are quite satisfactory. Although the expression of mRNA from FFPE is lower than fresh tissue (without fixation), but recent studies showed accurate value in qRT-PCR using FFPE(12-14). Since the frozen sample is limited and requires a large area thus the use of FFPE for qRT PCR examination become a solution ${ }^{15}$. Factors that should be considered in qRT-PCR examination using FFPE include:

Formalin used is a buffer with normal $\mathrm{pH}$ because the acidic conditions can lead to degradation of mRNA ${ }^{15}$.

1. Time fixation from tissue obtained is immediately after removal from the bodies to prevent autolysis process ${ }^{13,16}$.

2. Optimal fixation time is $12-48$ hours, because in some studies revealed decreasing mRNA expression after fixed more than 24 hours ${ }^{13,15,17}$.

3. Temperature and storage time of FFPE. Storage temperature should be $4{ }^{\circ} \mathrm{C}$ with a storage time of no more than one year, although this is still being debated ${ }^{13,15}$.

In this study, the level of expression of CXCR4 mRNA were higher in tissues derived from hospital compared to tissues derived from a private lab. It is possible because private laboratories receiving tissue from different areas with different types and duration of fixation which may affect mRNA expression. The use of non-buffered formaline and delayed tissue fixation also decreased mRNA expression as experienced byprivate laboratories who does not have facilities as complete as government hospitals.

In this study, the level of CXCR4 mRNA expression between breast cancer with lymph node metastasis and without metastasis were not significantly different. This is consistent with several studies that have been done before where the expression of CXCR4 was not associated with incidence of lymph node metastasis however is more associated with a poor prognosis ${ }^{10,18}$. Moreover in some studies CXCR4 expression in the breast is associated with bone metastasis ${ }^{18,19,20}$. This may be due to CXCR4 needs its ligands, namely CXCL12, wherein the difference in expression levels of CXCL12 between primary organ and sites of metastasis has an important role for metastasis ${ }^{6,8,11,21,22}$. Existing studies revealed that CXCL12 expression have more roles in the process of metastasis than CXCR4 expression ${ }^{21,22}$. As the study conducted by Wei $\mathrm{Wu}$ et al stated the significant difference between the levels of CXCL12 in primary organs and lymph nodes, while tumors with low CXCL12 levels at the primary organ and high levels at the lymph nodes have a tendency to metastasize ${ }^{22}$. Even the study about ovarian tumor has proven that CXCL12 can be used as a predictive factor of metastasis while CXCR4 cannot $^{23}$. According 
to Hassan et al, mortality of breast cancer increases in patients with both high expression of CXCR4 in the tumor and low CXCL12 in the plasma compared to the increase CXCR4 in tumor alone or lower CXCL12 level in the plasma alone ${ }^{11}$.

Nevertheless, several other studies have the opposite results where the expression of CXCR4 is associated with lymph node metastasis in breast cancer ${ }^{9,24,25}$. Although there is association between the increased expression of CXCR4 with incidence of lymph node metastasis, they convey varying results. A study by Kato et al found significant differences in the expression of CXCR4 protein via IHC staining on the expression pattern and the number of lymph nodes, although there was no significant difference between the groups with and without metastasis of lymph node metastasis $^{24}$. Variations of the expression pattern and vague cut-off point made it difficult to certainly conclude the role of CXCR4 in breast carcinoma using immunohistochemistry ${ }^{21}$.

The process of metastasis is a complex process influenced by many factors ${ }^{26,27,28,29}$. Pretranscription and posttranscription factors, epigenetic changes, and microenvironment greatly affec the expression of CXCR4. Normal tissue cells such as fibroblasts and endothelial cells express CXCR4 albeit in smaller amounts when compared with tumor tissue $^{30,31}$. In addition, the hypoxic conditions in primary tumor can lead to increased expression of $\mathrm{CXCR}^{7,29}$. This may can explain why there are three samples of breast cancer without lymph node metastasis have CXCR4 mRNA expression levels were very high. After exploring the patient history, two of the three samples obtained had undergone neoadjuvant chemotherapy. Chemotherapy causes cells undergo hypoxia and necrosis ${ }^{4}$. On the other hand hypoxic conditions triggered tumor cells to increase the expression of CXCR4. Subsequently hypoxic conditions will trigger cancer cells to express CXCR4 binding to CXCL12 endothelial cells involved in angiogenesis and migration of cancer cells into the bloodstream ${ }^{7,29,32}$. Nevertheless, the increased expression of CXCR4 alone without the support of other micro environment factors are not enough to cause metastasis.

Prognostic factors such as size, grading or age appear not directly related to the level of CXCR4 expression. This is in line with previous studies that revealed CXCR4 expression was not directly related to the clinicopathological features such as age, age and tumor size $\mathrm{s}^{9,21,24}$.

Hypoxic conditions is greatly influenced by the size and histological grade of the tumor. The larger the size and the degree of histological tumor would cause cancer cells susceptible to hypoxic conditions, which in turn triggers the process of angiogenesis and metastasis. Younger age in breast cancer is also associated with poorer prognosis because it deals with higher progressivity. But in study there has been no significant difference in mRNA expression levels of CXCR4 in all three clinicopathological aspects above which is in line with other existing research. This is possible because the complexity of environmental factors and processes that counfound the influence so that CXCR4 expression alone can not be used as the sole predicting factor.

Although this study found no significant association between CXCR4 mRNA expression with clinicopathological features in breast carcinoma, the role of CXCR4 on the breast should not be ignored. The administration of drug that inhibits the expression of CXCR4 proved to inhibit metastasis when given with chemotherapy ${ }^{33}$. This is possible because the administration of an antagonist of CXCR4 can inhibit CXCR4CXCL12 binding that plays a role in the 
progression, invasion and metastasis of tumors ${ }^{7,32,34}$.

This study has several limitations. One of them is limited clinical information from a sample in which the status of distant metastases (lung, bone, liver and other tissues) is unknown. So it is still possible samples without lymph node metastasis with higher expression of CXCR4 mRNA have metastasized to other organs. Sample variations and pre-analytic conditions such as type and duration of fixation can not be controlled because samples came from a wide area and diverse handling system so that it can affect the level of expression of CXCR4 mRNA. In this study, the samples used are not separated between the tumor tissue and surrounding tissue which can affect the outcome, even though it has been minimized by using the controls of normal breast tissue as a correction factor.

\section{CONCLUSION}

From this study we can conclude that CXCR4 mRNA expression was not associated with clinicopathological features of invasive (ductal) carcinoma NST. There were increased expression of CXCR4 mRNA in tumor tissue compared to normal breast tissue.

\section{ACKNOWLEDGEMENT}

The authors are grateful to Mr. Nur Eka and Mr. Sumantri for their excellent technical assistance.

\section{REFERENCES}

1. Colditz GA, Chia KS. WHO Classification of Tumours of the Breast: Invasive breast carcinoma: Introduction and general features. Int Agency Res Cancer,Lyon. 2012;4th edition(International Agency for Research on Cancer,Lyon):14-7.

2. Shulman LN, Willett W, Sievers A, Knaul FM. Breast cancer in developing countries: Opportunities for improved survival. $\mathbf{J}$ Oncol. 2010;2010.
3. Bhatia H. Breast Cancer in Asia. Gen Re. 2016;4:2-5.

4. Mukherjee D, Zhao J. The Role of chemokine receptor CXCR4 in breast cancer metastasis. Am J Cancer Res [Internet]. 2013;3(1):46-57. Available from:

http://www.pubmedcentral.nih.gov/articlere nder .fcgi? artid $=3555200 \&$ tool=pmcentre $\&$ rendertype $=$ abstract

5. Kryczek I, Wei S, Keller E, Liu R, Zou W. Stroma-derived factor ( SDF-1 / CXCL12 ) and human tumor pathogenesis. Am J Physiol - Cell Physiol. 2007;292(123):98795.

6. Furusato B, Rhim JS. CXCR4 and Cancer. Cancer Drug Discov Dev. 2009;31-46.

7. Jin F, Brockmeier U, Otterbach F, Metzen E. New Insight into the SDF-1/CXCR4 Axis in a Breast Carcinoma Model: Hypoxia-Induced Endothelial SDF-1 and Tumor Cell CXCR4 Are Required for Tumor Cell Intravasation. Mol Cancer Res [Internet]. 2012;10(8):1021-31. Available from:

http://www.ncbi.nlm.nih.gov/pubmed/2276 7589

8. Sun Y, Mao X, Fan C, Liu C, Guo A. CXCL12-CXCR4 axis promotes the natural selection of breast cancer cell metastasis. Tumor Biol. 2014;

9. Zhang Z, Ni C, Chen W, Wu P, Wang Z, Yin $\mathrm{J}$, et al. Expression of CXCR4 and breast cancer prognosis: a systematic review and meta-analysis. BMC Cancer. 2014;14(49):1-8.

10. Yu S, Wang $X$, Liu G, Zhu X, Chen Y. High Level of CXCR4 in Triple-Negative Breast Cancer Specimens Associated with a Poor Clinical Outcome. Acta Med. 2013; Vol.67(Okayama):369-75.

11. Hassan S, Ferrario C, Saragovi U, Quenneville L, Gaboury L, Baccarelli A, et al. The Influence of Tumor-Host Interactions in the Ligand / Receptor Axis in Determining Metastatic Risk in Breast Cancer. Am J Pathol. 2009;175(1):66-73.

12. Darash-yahana M, Pikarsky E, Abramovitch R, Zeira E, Pal B, Karplus R, et al. Role of high expression levels of CXCR4 in tumor growth, vascularization, and metastasis. FASEB J. 2004;28:1-28.

13. Ahlfen S Von, Missel A, Bendrat K, Schlumpberger M. Determinants of RNA 
Quality from FFPE Samples. PLoS One. 2007;2(12):1-7.

14. Smolinski D Von, Leverkoehne ÆI. Impact of formalin-fixation and paraffinembedding on the ratio between mRNA copy numbers of differently expressed genes. Histochem Cell Biol. 2005;124:17788.

15. Chung J, Braunschweig T, Williams R, Guerrero N, Hoffmann KM, Kwon M, et al. Factors in Tissue Handling and Processing That Impact RNA Obtained From Formalinfixed , Paraffin-embedded Tissue The Journal of Histochemistry \& Cytochemistry. J Histochem Cytochem. 2008;56(11):103342.

16. Abrahamsen HN, Steiniche T, Nexo E, Hamilton-dutoit SJ. Towards Quantitative mRNA Analysis in Paraffin- Embedded Tissues Using Real-Time Reverse Transcriptase-Polymerase Chain Reaction. J Mol Diagnostics. 2003;5(1):34-41.

17. Macabeo-ong $\mathrm{M}$, Ginzinger DG, $\mathrm{Ph} \mathrm{D,}$ Dekker N, Mcmillan A, Ph D, et al. Effect of Duration of Fixation on Quantitative Reverse Transcription Polymerase Chain Reaction Analyses. 2002;

18. Andre F, Xia W, Conforti R, Yongkunwei, Boulet $\mathrm{T}$, Tomasic G, et al. CXCR4 Expression in Early Breast Cancer and Risk of Distant Recurrence. Oncologist. 2009;14:1182-8.

19. Masuda T, Endo M, Yamamoto Y, Odagiri $\mathrm{H}$, Kadomatsu $\mathrm{T}$, Nakamura $\mathrm{T}$, et al. ANGPTL2 increases bone metastasis of breast cancer cells through enhancing CXCR4 signaling. Sci Rep. 2015;5:9170.

20. Cabioglu N, Sahin A, Doucet M, Yavuz E, Igci A, Engin O, et al. Chemokine receptor CXCR4 expression in breast cancer as a potential predictive marker of isolated tumor cells in bone marrow. Clin Exp Metastasis. 2005;22:39-46.

21. Kishima MO, Eduardo C, Oliveira C De, Banin-hirata BK, Losi-guembarovski R, Oliveira KB De, et al. Immunohistochemical Expression of CXCR4 on Breast Cancer and Its Clinical Significance. Anal Cell Pathol. 2015;2015:1-6.

22. Wu W, Qian L, Chen X, Ding B. Prognostic significance of CXCL12, CXCR4, and CXCR7 in patients with breast cancer. Int J Clin Exp Pathol. 2015;8(10):13217-24.
23. Popple A, Durrant LG, Spendlove I, Rolland P, Scott I V, Deen S, et al. The chemokine, CXCL12, is an independent predictor of poor survival in ovarian cancer. $\mathrm{Br} \mathrm{J}$ Cancer [Internet]. Nature Publishing Group; 2012;106(7):1306-13. Available from: http://dx.doi.org/10.1038/bjc.2012.49

24. Kato M, Kitayama J, Kazama S, Nagawa H. Expression pattern of CXC chemokine receptor-4 is correlated with lymph node metastasis in human invasive ductal carcinoma. Breast Cancer Res [Internet]. 2003;5(5):R144-50. Available from: http://www.pubmedcentral.nih.gov/articlere nder.fcgi?artid=314431\&tool=pmcentrez\&r endertype $=$ abstract

25. Ding Y, Li C, Yang Q, Chen C, Cheng Z. The Significance of CXCR4 Expression for the Prediction of Lymph Node Metastasis in Breast Cancer Patients. Chin J Clin Oncol. 2008;5:83-6.

26. Michal AM, Peck AR. Differential expression of arrestins is a predictor of breast cancer progression and survival. Breast Cancer Res Treat. 2012;130(3):791807.

27. Ramos EAS, Grochoski M, Braun-Prado K, Seniski GG, Cavalli IJ, Ribeiro EMSF, et al. Epigenetic changes of CXCR4 and its ligand CXCL12 as prognostic factors for sporadic breast cancer. PLoS One. 2011;6(12):1-9.

28. Al-souhibani N, Al-ghamdi M, Al-ahmadi W, Khabar KSA. Posttranscriptional control of the chemokine receptor CXCR4 expression in cancer cells. Carcinogenesis. 2014;35(9):1983-92.

29. Cronin PA, Wang JH, Redmond HP. Hypoxia increases the metastatic ability of breast cancer cells via upregulation of CXCR4. BMC Cancer [Internet]. 2010;10(1):225. Available from: http://www.biomedcentral.com/14712407/10/225

30. Xu C, Zhao H, Chen H, Yao Q. CXCR4 in breast cancer: oncogenic role and therapeutic targeting. Dove Press J. 2015;9:4953-64.

31. Tchafa AM, Ta M, Reginato MJ, Shieh AC. EMT Transition Alters Interstitial Fluid Flow - Induced Signaling in ERBB2 Positive Breast Cancer Cells. Mol Cancer Res. 2015;13(4):755-64.

32. Guo S, Xiao DAN, Liu H, Zheng X, Liu LEI, Liu S. Interfering with CXCR4 expression inhibits proliferation, adhesion 
Setyawan et al., Association of CXCR4 mRNA Expression with Clinicopathological Aspects of Invasive Breast Carcinoma

and migration of breast cancer MDA - MB 231 cells. Oncol Lett. 2014;8:1557-62.

33. Xiang J, Hurchla MA, Fontana F, Su X, Amend SR, Esser AK, et al. CXCR4 Protein Epitope Mimetic Antagonist, POL5551, Disrupts Metastasis and Enhances Chemotherapy Effect in Triple Negative Breast Cancer. Mol Cancer Ther. 2016;14(11):2473-85.

34. Nobutani K, Shimono Y, Mizutani K, Ueda Y. Downregulation of CXCR4 in Metastasized Breast Cancer Cells and Implication in Their Dormancy. PLoS One. $2015 ; 1-17$. 